\title{
ENVIRONMENTAL EDUCATION AS PART OF GEOGRAPHICAL COURSES IN THE CZECH REPUBLIC - PROBLEMS, SUGGESTIONS, AND CHALLENGES
}

\begin{abstract}
H. Kühnlová, K. Kühnl: Environmental Education as Part of Geographical Courses in the Czech Republic - Problems, Suggestions, and Challenges. - GeografieSborník CGS, 101, 2, pp. 158 - 168 (1996). - Improvement of the environment is conditioned by a systematic environmental education. The role of geography in such an educational system is also crucial. As a result, geographical courses require changes. A sound knowledge of one's local region much contributes to the understanding of environment in the broad sense. Environmental education must include the historical development of natural and social elements as well as future prospects. The concept of eco-museum could bring much inspiration to this process. The article deals with the idea of eco-museum of Cental European importance which should primarily influence the environmental thinking of the population.

KEY WORDS: geographical education - social aspects of environment - eco-museum - environmental history.
\end{abstract}

\section{Introduction}

Czech Republic ranks among countries with the greatest extent of environmental damages. In most regions this damage includes not only various kinds of air, water, and soil pollution, as well as destroyed forests and other natural features. Moreover, damage of the social environment is equally or even more important since it brings long-lasting consequences and improvements are difficult. Increased morbidity and mortality (including infant mortality) are generally viewed as the best indicators of the overall damage of human environment. These indicators are, however, likely to be influenced to a lesser extent by pollution of air and other nature components and rather more by the lifestyle, attitudes towards one's health and by the health service ${ }^{1)}$.

1) WHO (World Health Organization) claims that the quality of physical environment and lifestyle is by $80 \%$ responsible for the health of population and the level and organization of the health service accounts just for $20 \%$ (Dzúrová, D., 1993).

The international research project based in the Czech Republic "Teplice Programme" has come to similar results after 15 years of investigations. This project compares two regions: North-West Bohemia which has extremely damaged environment, and Prachatice District, South Bohemia, with high quality natural environment. So far, however, it has not been proved that damaged physical environment (especially air pollution) would influence the health of population more than improper lifestyle (bad nutritional habits, lack of physical activities, stress, smoking, impaired family relations, risky behaviour, etc.) (Rubeš, F., 1994).

Though the influence of damaged environment on human health is generally recognized, direct proofs that would support a close relation between the rate of environmental damage and mortality are rare (see Státní politika životního prostředí, Ministerstvo životního prostředí ČR, 1993). 
It seems more and more likely that most health indicators of the human enivronment and its damage are conditioned by a broad array of circumstances. Apart from natural factors also psychological factors and the quality of social environment ${ }^{2}$ play an important role. The quality of life, however, should not be reduced only to a reasonable state of health. It largely depends on other matters and facts many of which are closely related to space in general and contribute to the social climate (lifestyle, values, interpersonal relations, cultural level, attitudes towards traditions, leisure activities, etc.).

Such a complex approach towards the environmental issues and the quality of life should also be adopted in the environmental education and should become part of environmental awareness.

It is this awareness, however, which is on much lower level in Czechia compared with conditions in economically developed countries. The Communist regime banned many environmental information and provided no systematic environmental education. The roots of environmental degradation were not discussed or even hidden. Environmental issues received no official interest under Communism and the centrally planned economy postponed these problems to futere generations.

It will last long till environmental damages will be repaired and Czech population will again live in healthy conditions. Such a long-lasting process requires practical ecological provisions and also systematic environmental education: This education should stress intelligent and sensible approach towards natural and man-made structures. It also must encourage the role of behaviour and values that much contribute to the quality of social environment. Priority must be given to the concept of individual responsibility. Since environment is a complex concept, environmental education should be given a more important position in the framework of geographical education ${ }^{3)}$. It is necessary to sort and process more information from other scientific branch-

2) Social environment may be defined as the part of environment consisting of population itself, various population structures and interpersonal relations. Compared with the natural environment the social environment features material aspects (human beings) and also immaterial concepts as are language, culture, legal and ethic standards, traditions, values, etc. The quality of social environment is difficult to assess; it should be based on the complex quality of social indicators and social relations. The quality of social relations is influenced by the occurrence of negative social and demographic phenomena and features on one side and by progressive social facts on the other hand. As such, social relations indirectly indicate the quality of social environment (Illner, M. et al., 1989).

In the Czech Republic, many negative social attributes affecting the social environment occur in regions with the worst life conditions. These are typified by a high share of suicides, alcoholism and drugs, prostitution, children under threat, abortions, increased divorce rate, etc.

Social environment in the most devastated regions has been largely influenced by the degradation of countryside and the whole settlement structure. It included total clearance of many villages and towns, as well as negative changes of the urban landscapes (building of socialist-style housing estates). Ruthless approach towards cultural monuments was adopted and many were destroyed. All these aspects, however, occurred also in other Czech regions, though to a lesser extent.

3) Environmental information and data were first included in Czech geography courses on primary and secondary levels as late as in the 1980 s. Ironically, the importance of environmental education in Czechia has been even higher than in other countries. Apart from other reasons, the structure of geographical university education much contributed to such a delay. Environmental concepts were included into geographical courses at the university level later and to an incomparably lesser extent than in case of courses dealing primarily with 
es. Apart from the traditional links with natural sciences (especially with ecology) geographical education is supposed to include sociological and economic data as well as information produced by physical and regional planning. Historical development of all environmental components should also be taken into account. It is most likely that geographical education enriched in the above mentioned way would occupy more significant position in the process of raising environmental awareness and improving the quality of life especially among the young generation. To achieve this goal, however, it is necessary to alter the contents of geographical education on primary and secondary levels. Also university courses that provide training for future geography teachers need changes.

\section{Environmental Issues as Part of Geographical Education}

The concept of landscape ecology and assessing of socioeconomic landscape components (including basic principles of regional planning) have received a great interest among school geographers, textbooks authors, and teachers in developed countries over the past decade. Human values, behaviour, and responsibility are viewed as part of the decision-making process. Moreover, the scope of education clearly tends towards the extension beyond geographical boundaries: students and pupils recieve a wide range of information based on interdisciplinary contexts. Currently there are two main directions. First, the education focuses on global problems and problem regions of the world. Second, deeper understanding of the domestic region, town, and place of residence is stressed; raising of environmental awareness is viewed as very important.

The above mentioned approach conforms the basic principles of the IGU International Charter of Geographical Education ${ }^{4)}$. The Charter emphasizes the importance of geography for the environmental awareness of future generations.

The Czech educational system gradually adopts the general trends in geographical education and its contents. Sections on landscape and environment were first included in teaching programmes and geography textbooks on primary and secondary schools at the turn of 1970 s and 1980 s. Information on

biology, chemistry, agronomy, and even with some technical sciences. A general beleif that environmental issues have little to do with geographical education and research long prevailed among the Czech geographical community. As a result of this delayed and careful approach towards environemntal concepts, the geographical methodology of assessing the environmental quality received little attention. Geographers just described the state of environmental damage or the protection of natural components. A complex approach towards the environment was rarely adopted and concerned first of all only the natural sphere. Sociogeographical aspects of the environment are still taken into account only exceptionally, both in empirical research and in the framework of theory and methodology. Though synthesis is one of the basic geographical concepts, in the case of environmental issues this approach has not been adopted over many years. This fact is reflected also in the geographical education. Description still prevails and individual environmental components are just classified. Complex approach towards environmental issues based on solving problems is rare.

4) The International Charter of Geographical Education was approved by the participants of the 27th IGU Congress in Washington D.C., 1992. The Charter calls for general attention to geographical education and to its key role in the process of shaping future generations responsible for this world (Haubrich, H., 1994). 
nature protection and quality of life (perceived as the level of man-induced damage of natural environment), on the most damaged regions and partly on measures taken to improve the state of environment in Czechoslovakia and abroad received more and more interest in the course of $1980 \mathrm{~s}$. Before the political changes in 1989, however, the environmental "education" was limited just to partial information. Deeper investigations were not presented, the roots of topical problems were not discussed and little attention was given to possible solutions. Many facts were falsified or even tabooed and information misinterpreted. The regime did not encourage open discussions about the environmental devastation that included open pit mining, plants based on burning of low quality coal, and toxic waste in water and soil. As a result, sound and complex environmental training was not supported. The education was much focused just on the necessity to protect natural components against pollution.

Relatively important changes have been enforced over the past five years $(1990-1995)$ in the field of general concept, contents and methodology of the environmental education in the Czech Republic. Above all, information on the state of the environment are not banned any more and real roots of the environmental problems are discussed and assessed. Environmental issues became integral part of many geographical courses and programmes. The improvement of environmental knowledge is now perceived as one of chief targets geographical education should be aimed at. Geographical textbooks released after 1989 also devote much more attention to environmental problems.

The application of recent educational trends much depends on teachers, their activity and scope of knowledge. The traditional educational concepts still much influences most teachers. The young generation, however, rapidly adopts new ways of thinking and the practical educational process gradually becomes to conform West European standards. The general prestige of geography as a subject is thus likely to be increased.

The environmental section of geographical education in the Czech Republic will be influenced by practical needs. It also will reflect foreign experience in this field. The main trends in foreseeable future should be based on the following ideas:

a) The knowledge of local region and municipality should be extended. Environmental and landscape changes in the past and resulting consequences must be stressed. It is necessary to devote more attention to future environmental development including desired changes of rural and urban landscapes, quality of housing, interpersonal relations, and generally the quality of life.

b) Geographical education should emphasize the activities and abilities needed for the environmentally responsible decision making (issues concerned with housing, new planning and landscape concepts, etc.). More attention should be devoted to activities, discussions, projects, and scenarios concerning the development of society within the environmental framework.

It is especially important to promote the idea of personal responsibility for sustainable development and generally raise the global environmental awareness.

a) To extend the knowlege of local region and place of residence is an efficient way how to link geographical education with environmental issues. It 
also creates conditions for improving the human attitudes towards local area, especially among youngsters ${ }^{5}$. Deeper local knowledge enables comparison with other regions and creates a sound base for understanding the coexistence between society and environment. Theoretical statements and isolated pieces of information concerning environmental damages are thus replaced by a broader approach towards historical contexts of the state of local environment. The interconnection between the perception of local landcscape or local settlement and the general landscape development is especially important. The detailed scale also enables to observe the everyday life. If students would understand the current state based on the knowledge of the past, they would be more likely to adopt knowledgeable approach towards the future and undertake environmentally responsible decisions.

b) Observation of the local environment produces a diverse material for informal environmental education. Natural and social features can be described, sorted, and assessed in field classes. Some projects and scenarios aims to solve real (or simulated) problems. Activities focused on improving the local environment and on raising the environmental awareness of students' families should also be supported. Regular discussions on current issues of local, national, and global importance are important, too, as are round tables with invited guests of various professional background. Leisure time of youngsters should be enriched by activities concerned with environmental protection and sustainable development.

Generally, environmental education should be more future-oriented (in the sense of future space-time relations) and based on examples from familiar regions. To do so, it is necessary to combine the assessment of natural and social components and adopt integrated educational approaches.

The transition of geographical education aims to deepen the environmental thinking of Czech population. The basic approach towards environmental studies as part of geography, however, should be changed.

\section{The Concept of Eco-Museum as a Method how to Extend Environmental Thinking and Enrich Geographical Education}

Geography as a scientific discipline undergoes permanent changes. Environmental issues in the broad sense as well as historical contexts become increasingly important in current geography. The environmental aspects of historical development are devoted great attention in many developed countries. Taking such contexts into consideration could iniciate changes in contents and scope of Czech geographical education, too.

The environmental history ranks among the modern historiographic subdisciplines. It studies ecological aspects of historical events in the broad context. Related to the environmental history is the historical geography of environmental changes - discipline which has originated in Europe in mid-1980s. Environmental history is the history of nature and its changes as perceived by humans; the history of natural images reflected in ideas, culture, and art;

5) The experience from geographical education in developed countries, for instance in Switzerland, has proved this fact (Aerni, K. et al., 1993). The same is true with foreign geographical courses, programmes, and textbooks in Germany, Austria, etc. (Geographie 1985, Lehrplan 1991). 
the history of environmental politics. Environmental historians continue to emphasize the links with other scientific branches - with geography, ecology, sociology, philosophy, etc. Environmental history ${ }^{6)}$ has developed rapidly especially in the U.S.A. (Jeleček, L., 1993).

Neither Czech geographers, nor historians have systematically studied the environmental aspects of human history so far. The knowledge of history, however, could much contribute to the process of environmental repairs and to raising the environmental awareness.

The concept of eco-museum ${ }^{7}$ is an example of the historico-geographical approach towards the environmental studies at a small regional scale. The eco-museum itself proves how important for geographical education are links with history, ecology and other branches as ethnology, urban planning, history of culture and architecture, sociology, technical sciences, economics, philosophy, etc.

G. H. Riviére, father of the eco-museum concept, conceived it in the end of 1970 s as an integral image of nature and life on a relatively small area over a certain period of time. The idea of spacial development has thus been stressed. Riviére's ideal eco-museum would show human beings as part of dynamic bilateral relations between man and environment. Under the term "environment" he understood the entire space, the realm of nature and culture. Apart from the rural environment, often shown in vernacular architecture reserves, the Riviére's concept also includes the urban and industrial environment. A permanent exhibition shows the historical development and the character of respective region is documented in crucial stages of natural and human history up to the present. Future prospects are also included. Important realities that directly influence the future development are emphasized. Apart from the permanent historical exhibition the eco-museum also contains natural and cultural features in the open air that typify the area and contribute to the understanding of local environment. These include rural, urban, and industrial architecture, historical sites, archaeological findings, natural phenomena (geological freaks, habitats of unique animals and plants), typical man-induced structures, etc. Such objects are linked with introductory trails and provided with written information ${ }^{8}$. This idea, however, does not allow to place an eco-museum under one roof. In contrast to an eco-museum, a traditional museum is usually concerned with a larger region and the local population does not directly take part. On the contrary, the Riviére's eco-museum concept underlines the role of local people. Locals are

6) Environmental history should be distinguished from historical ecology. The former deals with the development of nature-society relations and their positive and negative consequences on both sides. The latter studies namely negative aspects of human activities in the sphere of nature (Jeleček, L., 1993).

7) To a certain extent, the idea of eco-museum in general has been influenced by the crisis of traditional museums. These do not reflect modern needs and new forms are looked for. Georges Henri Riviére, founder of the Museum of Folk Art and Traditions in Paris, first promoted the idea of eco-museum (Hinten, W., 1985, Riviere, G. H., 1985). The word "eco-museum" which reflects the special environmental concern has been first created by Huguesde Varine Bohan, Riviére's successor in the International Council of Museums. R. Poujad, French Minister for Environment, officially approved this term.

8) The idea, aims, and practical forms of an eco-museum, however, differs significantly from museums in the open air, vernacular architecture reserves, and introductory trails that have more limited scope. 
invited to cooperate according to one's abilities and interests. Since they are asked to contribute with their knowledge and experience and as such to influence the future development of their domicile, locals mostly take the creation of eco-museum seriously. Being co-authors, local people are also likely to take part in promotion and advertising ${ }^{9}$.

France was the first country that has pioneered eco-museums since 1980s (Ecomusée de la Grande Lande de Gascogne, Ecomusée du Mont Lozere, Ecomusée de la communauté urbaine Le Creusot-Montceau-les-Mines, etc.). Other developed countries such as The Netherlands and Switzerland followed.

We take the structure and purpose of the Simplon Pass Eco-Museum, Switzerland, as an example.

The foundation that has built this museum in between 1991 and 1996 aims to provide visitors with a comprehensive picture of the economic and cultural life in the Simplon region. It is located on the important ancient trade route over the Alps in a unique natural environment. The Simplon Eco-Museum administration is housed in the rconstructed historical building at Simplon-Dorf. Permanent exhibition on local history opens there in July 1996. The main focus, however, is put on the reconstructed Stockalper Route that came into existence in the 17 th century and followed the mediaevel route over the pass. The latter linked Northern Italy with French market places. Brig in the Rhône Valley and Gondo at the Italian border were important settlements at both sides of the pass. This trade route provided the source of living for local population over more than one hundred years and it brought prosperity to the whole region. The reconstruction aims to preserve the route for Swiss people and foreigners passing over Simplon. Selected natural and cultural objects scattered along the $35 \mathrm{~km}$ long section gradually become parts of the eco-museum. Apart from the reconstructed route itself these are former store houses, 17th century shelters and huts, mountain pub and chapel of the same period, etc. The eco-museum management also aspires to acquire some histrocally important monuments that would house various regional exhibitions (Kühnlová, H., 1993).

The concept of eco-museum is based on the study of local development and should result in a complex picture of the respective region. It is a picture of nature which has been gradually changed by humans and a picture of cultural and ecomomic activities that are largely influenced by the natural and social environments. Apart from the local context also relevant national and international circumstances are presented.

The eco-museum ensures the protection, restoration, and revitalization of natural landscape and man-made structures. It is also concerned with revival of traditions and conservation of cultural monuments.

Educational programmes and raising the public awareness are important issues, too. These include widening of interests among locals and enriching the tourist and recreational activities as well as the upgrading the knowledge on local region in the framework of general education.

9) The organizational structure of and eco-museum is usually based on three committees with precisely specified tasks: scientific committee, users committee, and administrative committee.

Members of the scientific committee are mostly university scholars - experts in various branches. The selection is influenced by practical needs of the respective region. Generally, experts in geology, biology, geography, natural and social ecology, archaeology, general history, art history, ethnology, agronomy, and other branches take part.

Local people become members of the users committee. They are grouped into various supporting associations and clubs.

Institutions providing the financial support and management of the eco-museum have representatives in the administrative committee. 
In general the eco-museum should contribute to upgrading the status of the respective region in people's minds and to enforcing local roots. All this is based on a deeper knowledge of local environment and local affairs. This improved knowledge and changes in behaviour that include accepting more responsibility in decision making are part of the local patriotism and pride.

The stimulative ideas on which eco-museums are based could be well applied in the Czech Republic, too. Czechs are mostly educated people and the country boasts old cultural traditions. Many Czech citizens have a wide range of interests including reading, regular trips, visits to museums, monuments, and introductory trails. These activities are especially frequent among young families. Since the standard of living in Czechia is expected to rise under new conditions, it is likely that based on the long-time experience new introductory trails will come into existence and also eco-museums might be built.

The coal mining region in North-West Bohemia would be an ideal setting for such an eco-museum. This area suffers from high air-borne pollution and severe devastation that rank among the worst of all Europe.

The landcapes of North-West Bohemia have been devastated by the ruthless opencast coal mining and by high concentration of coal-fired plants. Some parts really resemble a lunar landscape: giant open pits, huge heaps of useless waste, polluted underground water, hazardous dumps, and devastated forests.

This region was inhabited by Germans and Czechs side by side over many centuries. Thus, it was a setting of unique historical development. Fifty years ago, however, an important population change ocurred there: Germans were expelled and the region has been resettled by people from various parts of Czechoslovakia. North-West Bohemia suffered from a large migration turnover also under the following "socialist" period. The stability of local population remained low over a long time. The border regions show a large population instability even now.

High level of social pathology is typical for North-West Bohemia. The local population is by Czech standards less educated. The relatively high proportion of Gypsies (Romanies) makes a lot of problems, too, since many do not accept the general social standards. Certain diseases are more frequent due to the unhealthy way of living that also contributes to higher divorce rate, criminality, and dependence on narcotic drugs.

The historical part of North-West Bohemian eco-museum would focus on main stages of development from the ancient times up to the present. The gradual environmental devastation resulting in a total damage would be demonstrated at the background of social development. The settlement history, population composition, as well as the destruction of social environment under Communism would be shown.

Typical natural and cultural phenomena of this region - witnesses of the landscape degradation - would form parts of the eco-museum, too. There would be examples of reclamation and forest revitalization. Devastated cultural monuments as well as those that escaped damage would be shown (Most, Jezeři Castle), and also the prefabricated "socialist" architecture. Some urban sites are ideal candidates to become parts of the eco-museum, too: Kadañ (historic town), Duchcov (historically important town where the urban structure has been recently deformed), and Teplice (the spa district). Other routes could direct visitors to the attractive recreational areas outside the coal mining region, as are Děčínské stěny (Děčín Rocks), and České Středohoří (Bohemian Highlands). Some environmentally friendly establishments could be linked to a separate exhibition focused on the changing environment in North-West Bohemia. These could include an ecological dump site, coalfired plant, industrial factory, or a residential area. The issue of through truck traffic should be demonstrated, too. The exhibition itself should be located in a carefully selected place where examples of the recent damage would be seen. Ideally, it would become an important centre for environmental education.

Creation of such an eco-museum in the coal mining district of North-West Bohemia would inevitably bring many problems to cope with. Compared to the existing eco-museums throughout Europe it would be interspersed on quite a large region (approx. $1,500 \mathrm{~km}^{2}$ ) which does not attract much tourism and recreation in the traditional sense. 
The eco-museum, however, should become a touristic destination, too. Moreover, the area of interest will continue to face complicated technical, economic, environmental, and social problems. Nevertheless, putting the eco-museum idea in action would much contribute to upgrading the environmental education. Regarding the size and scope it would become a unique project in the European context.

North-West Bohemia would take benefits from the eco-museum, too. It would undoubtly increase the local environmental awareness and contribute to the improvement of social climate which is a crucial condition in the process of environmental upgrading ${ }^{10}$.

The concept of eco-museum gives a complex picture of the environmental conditions in a selected region. It proves that complex landscape studies make sense. The historical approach is crucial in the process of making oneself familiar with the respective region which is an essential condition for understanding the past development and current problems and for future considerations. This broad approach towards the environment could much enrich the environmental education and also improve the level of courses on regional geography in the modern sense.

\section{Conclusions}

Environmental awareness and environmental thinking must be upgraded if the environment in the Czech Republic should be improved. Geographical education that encompasses both the natural and social aspects of the environment should in future become more concerned with environmental knowledge and activities. Practical education should ever more be focused on the environmental responsibility as a message for future generations and on encouraging values necessary for a better quality of life. Such a shift, however, reguires reformes in the essence of teaching geography. The traditional descriptive form and separate assessment of individual geographical aspects should be replaced by an integrated environmental concept. In order to successfully make this difficult transition of geographical education, geography as a science needs structural and conceptual changes, too.

Eco-museums are institutions that trace the environmental history of small regions from the ancient times to the present and suggest how the future trends could be like. Eco-museums effectively contribute to raising the environmental awareness and encourage the environmental concept as part of geographical education. Since the Czech environment is infamous and ranks among the worst in Europe, the authors take the opportunity to suggest the project of eco-museum in the coal mining region of North-West Bohemia. This proposed eco-museum would have brilliant prospects to become an important Central European centre for environmental education.

10) There are many other Czech districts where an eco-museum - if properly managed would contribute to protection of cultural monuments and to nature conservation. Let us mention the National Parks: Krkonoše (Giant Mountains), Sumava (Bohemian Forest), and Podyjí. The early industrial regions (Kladno, Ostrava, Liberec-Jablonec) would also provide a suitable setting, as would the spa district in West Bohemia, the Trrebon region dotted with lakes and cultural monuments, Valašsko (East Moravia), and others. 
AERNI, K., ENZEN, P., KAUFMANN, U. (1993): Landschaften der Schweiz. Geographica Bernensia, Bern. Band I, 115 s., Band II, 549 p.

BAUER, L. (1986): Erdkunde für Gymnasien in Bayern 11. Schroedel, Berlin, 144 p.

BOYLAN, P. J. (1982): The New Role of a Regional Museum Service in Environmental. In: Museums Journal, The Museums Association, vol. 82, No. 1, London, pp. 21-23.

HAUBRICH, H., ed. (1994): International Charter on Geographical Education. Commission on Geographical Education IGU, Freiburg.

Das Museum auf Wanderschaft (1993). Beilage zum Walliser Bote vom 25. September 1993.

DZÚROVÁ, D. (1993): Zdravotní stav obyvatel a kvalita životního prostředí. Regionální souvislosti. Kandidátská disertační práce, UK Praha, 136 p.

Geographie und Wirtschaftskunde. Lehrplan-Service. Kommentarheft 1, 2. Österreichischer Bundesverlag, Wien 1985, 145 p.

HINTEN, W. (1985): Zur Konzeption des Ecomusée in Frankreich. In: Kulturgeschichte und Sozialgeschichte im Freilichtmuseum. Museumsdorf Cloppenburg, p. 88-101.

ILLNER, M. et al. (1989): Regionální problémy sociálního rozvoje ČSSR. Expertizní studie. Ústav pro filozofii a sociologii ČSAV, Praha, $88 \mathrm{p}$.

JELEČEK, L. (1994): Nová historiografie? Environmentální dějiny v USA: vývoj, metodologie, výsledky. Český časopis historický, 92, No. 3, Praha, pp. 510-540,

KROSS, E. (1991): "Global denken - lokal handeln" - Eine zentrale Aufgabe der Geographie-Unterrichts. In: Geographie heute 12, H.93, pp. 40-45.

KUUHNLOVÁ, H. (1994): Simplonský průsmyk - historická dopravní trasa a projekt ekomuzea. Geografické rozhledy, 4, No. 4, Praha, pp. 98-101.

KÜHNLOVÁ, H. (1995): Zeměpis pro život. Pracovní učebnice. Nakladatelství ČGS, Praha.

Lehrplan für das bayerische Gymnasium. Fachlehrplan für Erdkunde. Amtsblatt des Bayerischen Staatsministeriums für Unterricht, Kultus, Wissenschaft und Kunst. Teil 1. München 1991, pp. 1325-1380.

LOB, R. E. (1995): Schulgeographie und Umwelterziehung vor neuen Aufgaben. In: Praxis Geographie 7-8, pp. 74-76.

MAUDE, A. (1992): Integrating Human and Physical Geography? Teaching a First Year Course in Environmental Geography. In: Journal of Geography in higher Education. Vol. 16 (2 issues).

MYERSON, G., RYDIN, Y. (1994): "Environment" and planning: a tale of the mundane and the sublime. In: Environment and Planning D: Society and Space 1994, vol.12, pp. 437-452.

RIVIÈRE, G. H. (1985): Définition évolutive de l écomusée. In: Museum, UNESCO, Paris, n. 148 (v. 37, n. 4).

RUBES̈, F. (1994): Zdravotní program Teplice. Geografické rozhledy, 4, No. 2, Praha, p. 59.

SCHLAPPI, CH., BADILATTI, M. (1995): Unser Quartier. Ein Unterrichtsmittel über Quartierentwicklung und Ortsbildpflege am Beispiel des Thuner Westquartiers. Berner Heimatschutz, Bern, 80 p.

\section{Shrnutí}

\section{ENVIRONMENTÁLNÍ VÝCHOVA JAKO SOUČÁST GEOGRAFICKÉHO VZDĚLÁVÁNÍ V ČESKÉ REPUBLICE - PROBLÉMY, NÁMĚTY A VYYZVY}

Česká republika patří mezi země s nejrozsáhlejším poškozením životního prostředí. Ve většině postižených území však nejde jen o rủzné stupně a projevy poškození přírodních složek krajiny. Stejně významné, a mnohdy významnější ve smyslu dlouhodobých dủsledků a obtížnosti náprav, je narušení sociálního prostředí.

Zvýšená nemocnost a úmrtnost obyvatelstva, které jsou nejčastěji považovány za nejprůkaznější indikátory celkové narušenosti životního prostředí člověka, jsou pravděpodobně menším dílem zpưsobeny poškozením ovzduší a ostatních přírodních složek prostředí a spíše větším dílem celkovým životním stylem, postojem a chováním lidí $\mathbf{k}$ vlastnímu zdraví a úrovní zdravotní péče. Prokazuje se, že úroveň zdravotních indikátorů narušenosti životního prostředí je důsledkem působení podstatně širšího okruhu faktorů, mezi nimiž kromě faktorů prírodního charakteru zaujímají významné místo také faktory psychologické a kvalita sociálního prostředí. Sociální prostře dí má na rozdíl od přírodního prostředí nejen svou materiální složku, ale i složku nemateriální (způsob života, kulturní vyspělost 
obyvatelstva, právní a morální normativy, hierarchie životních hodnot, mezilidské vztahy, vztah k tradicím, využití volného času atd.). Kvalita sociálního prostředí je těžko měřitelnou veličinou, kterou je nutno odvozovat od kvality komplexu sociálních znakủ a vztahů obyvatelstva. $\mathrm{Na}$ základè intenzity výskytu sociálnè patologických, negativních demografických a naopak sociálně progresivních jevủ lze hodnotit rủznou kvalitu sociálních vztahů a indikovat tak neprímo i kvalitu sociálního prostředí.

Chápání životního prostředí a kvality života $v$ tomto širším kontextu je nezbytné postupnè promítat do celkového environmentálního uvědomění obyvatelstva, které je jedním z nezbytných předpokladủ pro zkvalitnění životního prostředí v České republice. Je proto zapotrrebí prohloubit environmentální výchovu ve všeobecném vzdělávání a $v$ jeho rámci pak podstatně zkvalitnit environmentální složky geografického vzdělávání.

Nižší úroveñ environmentálního uvědomění obyvatelstva České republiky ve srovnání s obyvatelstvem nejvyspělejších zemí je dủsledek záměrné neinformovanosti a chybějící soustavné environmentální výchovy $v$ období minulého režimu.

S odvoláním na soudobé světové trendy ve vývoji obsahu geografického vzdèlávání zaměrující se stále více na životní prostředí a kvalitu života se v článku konstatuje naléhavá potřeba přestavby platných učebních osnov zeměpisu na všeobecně vzdělávací škole. Tato transformace však není myslitelná bez určité proměny $v$ př́stupech ke studiu životního prostředí v geografii jako vědním oboru, $z$ něhož školská geografie vychází.

Do výuky zeměpisu na obou stupních všeobecně vzdělávací školy v České republice se širší informace o životním prostředí dostaly teprve v 80. letech. Jednou z příčin opožděného nástupu $\mathbf{k}$ této problematice, jejíz důležitost a nalěhavost vystupovala v České republice ještě výrazněji oproti jiným zemím, byla také skutečnost, že česká univerzitní geografie se začala ekologickou tematikou systematičtěji zabývat podstatně později a v nesrovnatelně menším měřítku než jiné vědní discipliny (biologie, chemie, agronomie a některé další technické obory).

V úvodu kapitoly o zaměření obsahu geografického vzdělávání na životní prostředí jsou stručně shrnuty hlavní směry zájmů školských geografủ ve vyspělých evropských zemích.

Po shrnujícím přehledu vývoje pojetí a obsahu výuky o krajině a životním prostředí v České republice a po informaci o hlavních koncepčních změnách po roce 1989 jsou uvedeny dva důležité a dosud opomíjené úkoly rozvoje koncepce environmentálních složek geografického vzdělávání:

a) Prohloubit poznávání místního regionu a obce se zaměřením na dějinné souvislosti proměny krajiny a vývoje životního prostředí.

b) Výrazněji orientovat výuku zeměpisu na činnosti a na dovednosti rozhodovat se s ohledem na životní prostředí (např. v rámci bydlení, při diskusích o plánovaných změnách $\mathbf{v}$ sídelních útvarech i v krajině apod.), věnovat více prostoru činnostem, diskusím, projektům a scénářmm zaměřeným na vývoj společnosti v prostředí.

Autoři článku dále doporučují širší a integrovaný přistup při poznávání životního prostředí místního regionu obohacený o historický a také futurologický pohled na vývoj př́rodní i sociální složky krajiny. Za myšlenku podnětnou pro pojetí geografie menší oblasti i pro posílení environmentální výchovy obecně je autory považována koncepce ekomuzea.

Ekomuzeum je chápáno jako interpretace přírodní i sociální složky menšího krajinného celku prostřednictvím historické expozice v centrální budově muzea a na ni navazujících př́rodních i kulturních objektů přímo $v$ krajině, které představují reprezentativní prvky dokládající koexistenci člověka a prostředí v dějinném vývoji. Tvorba ekomuzea založená na výzkumu vývoje regionu směřuje $k$ vytvoření komplexního obrazu oblasti - obrazu př́rodního prostředí měnícího se postupně pod vlivem člověka a obrazu kulturní a hospodářské činnosti člověka ovlivňované přírodním i sociálním prostředím, a to nejen $\mathrm{v}$ měřítku místním, ale i v širších regionálních souvislostech národních i nadnárodních.

Stat obsahuje námět na vybudování ekomuzea středoevropského významu, a to $\mathrm{v}$ pánevním prostoru severozápadních Čech, který v rámci Evropy patří $\mathrm{k}$ oblastem $\mathrm{s}$ největším znečistěním ovzduší, s rozsáhlou devastací krajiny a s narušeným sociálním prostředím.

C̆lánek je výzvou $\mathrm{k}$ prestavbě pojetí a obsahu geografického vzdělávání, které by se v budoucnu mělo podstatně významněji podílet na ovlivňování environmentálního myšlení obyvatelstva.

(Authors are with Dpt. of Social Geography and Regional Development, Faculty of Science, Charles University, Albertov 6, 12843 Praha 2.) 